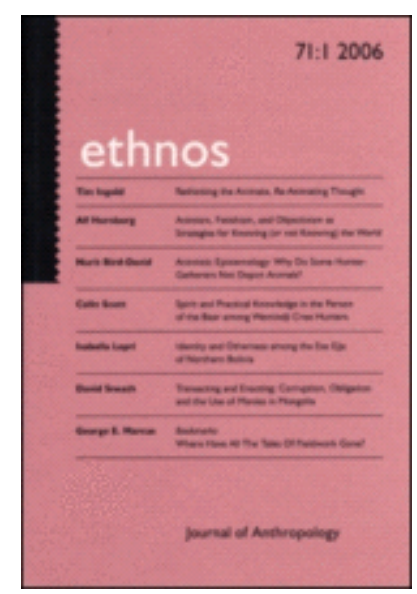

\title{
Ritual and ambiguities of social (dis)order in East New Britain.
}

\begin{tabular}{|r|l|}
\hline Journal: & Ethnos: Journal of Anthropology \\
\hline Manuscript ID & RETN-2018-0099.R1 \\
\hline Manuscript Type: & Special Issue Paper \\
\hline Keywords: & RItual, Papua New Guinea, Reciprocity, Society, Ambiguity \\
\hline
\end{tabular}

\section{SCHOLARONE ${ }^{\text {M }}$ \\ Manuscripts}




\title{
Ritual and ambiguities of social (dis)order in East New Britain.
}

\begin{abstract}
This paper explores the namata ritual, common among Tolai people in Papua New Guinea's, East New Britain Province. The namata is often presented as an event that contributes towards social order, both in the ethnographic record and by Tolai themselves. The namata is often experienced however as being highly ambiguous as various actors use the ritual to make sense of and intervene in hazardous processes of social change. In particular, the namata is a site where anxieties about perceived breakdowns of the socially cohesive power of reciprocal obligation are expressed and attempts are made to halt their corrosion. Paradoxically however these attempts are made from a position that is often experienced by those that they attempt to discipline as themselves being expressive of that very breakdown of reciprocal obligation, thus intensifying the sense that the namata has now become a site for the creation of uncertainty rather than social stability.
\end{abstract}

\section{Keywords}

Ritual, Papua New Guinea, Reciprocity, Ambiguity, Society.

Word count: 8351 


\section{The namata}

The namata, is a ritual conducted at some Tolai villages in Papua New Guinea's, East New Britain Province, that ideally involves the seclusion of the first-born son of a family in 'the bush' for a period of time, before his ritual revelation'. On the occasion of his ritual revelation, those in attendance, will present him with amounts of tabu or shell-wealth. This is ideally used to pay for the young man's bridwealth. In the past, the ethnographic record suggests that the namata only took place after the young man had married (A.L. Epstein 1969:218-221). Today it commonly occurs before marriage, sometimes before a bride has even been arranged for the young man, in which case, the tabu enters the young man's family's store of wealth (Simet 2014:194-195), where it will be available for future customary expenses (including any subsequent marriage).

The namata is often presented as the site for the reproduction of particular types of social relations based upon reciprocal interdependence, that will be familiar to many from the regional ethnographic literature. A.L. Epstein (1969:220), who conducted long term research at Matupit village for periods between 1959 and the early 1990s

\footnotetext{
${ }^{1}$ The Tolai are among the largest and well-known of PNG's ethnic groups. They were among the first groups to receive both Christian missions and education in the early colonial era and became known throughout the twentieth century as something of an educational and political elite. This position had become increasingly insecure at the time of my field research in the early 2000 s, due in part to a long process of economic growth in other regions and in part to the volcanic eruption that devastated the regional capital of Rabaul and surrounding Tolai villages, such as Matupit, where I conducted my research. The story of the Tolai is told in more detail in Epstein (1969) and Martin (2013).
} 
describes how the namata operates within a wider web of social obligation that it helps to reconstitute in the following words;

[E]ach contribution imposes on the recipient an obligation to reciprocate on some subsequent occasion. From this point of view, the namata provides an arena within which standing obligations are fulfilled and new debt relationships incurred. The full significance of the namata ... only emerges therefore when it is set in the context of an ongoing series of exchanges and distributions of various kinds.

All of which remained the case in many regards at the time of my fieldwork 40 years later. Any Tolai, regardless of their degree of enthusiasm for customary ritual such as the namata, would agree with Epstein that it provided an arena for fulfilling and making new debt relationships that could only be fully understood within the context of wider networks of such relationships and exchanges.

These interlocking obligations upon which namata depends and of which it is a constituent element are sometimes presented as being the basis of the underlying order of Tolai society. Even in comparatively recent accounts, namata is presented in a manner suggestive not only of an underlying social order, but one that presents itself in an almost Radcliffe-Brownian fashion as the power of a Society that stands above individuals and imposes its power upon them. So, Tateyama (2006:28) describes the, 'coming-of-age ceremony for a boy, which is called varkinim (or namata)', as a rite of passage by which, 'by which an individual is brought into a wide network of social relations and comes to be in debt to society.' Simet (2014:183) similarly describes of 
namata ceremonies how, 'In the end they are about checking, rekindling and reinforcing kinship relations', in a chapter on the namata that appears in a book section revealingly entitled, 'Relationships and Social Cohesion'. Simet's presentation is worth taking seriously as that of someone who is both a fully trained anthropologist (with a $\mathrm{PhD}$ from the Australian National University) and as a Tolai from Matupit who himself is deeply involved in these rituals. As we shall see, a presentation of namata as a ritual which makes social order through the reproduction of reciprocal obligations and interdependencies is one that other Tolai make as well. But it is a presentation that is not necessarily considered desirable or viable by many other Tolai. Such presentations of namata have to increasingly be considered not as descriptions of the ritual, so much as part of its performance, attempting to highlight particular interdependencies that the ritual itself is supposed to make apparent in order to achieve the desired social effect.

\section{Matthew's namata. $28^{\text {th }}$ September 2002.}

The usual singing and dancing entrance. Cllr Charles ${ }^{2}$ introduces prayers. Charles is MCing in a Kool t-shirt. ToDoppel collects the mat and a large coil of tabu. His face is one half white one half orange. It's a bit Bravehart. I think he throws the tabu on the pal na pidik ${ }^{3}$ to buy it for his other pubus ${ }^{4}$ namata next week.

\footnotetext{
${ }^{2}$ I use pseudonyms throughout this extract from my field-notes. Throughout the rest of the text when I am using extracts from material written by A.L. Epstein I use the real names of the persons involved as they appear in his writing, except in two cases where I change them to accord with the pseudonyms used for these persons in my writing.

${ }^{3}$ Pal na pidik literally translates as 'House of secret(s)' in the Tolai vernacular language Kuanua. It currently is used to refer to a structure in which the boy who has been secluded in the bush is ceremonially revealed at the namata.

${ }^{4}$ Pubu (more commonly written 'bubu' is the term for grandchild or grandparent in the national lingua franca of PNG, Tok Pisin.
} 


\footnotetext{
${ }^{5}$ Line of papamama tupelo wantaim (Tok Pisin) would most literally translate as the clans or extended lineage groups of both parents together.

${ }^{6}$ Olgeta lain bilong ples (Tok Pisin) meaning all the remaining general population of the village.

7 The meri bilong lain bilong papa go insait (Tok Pisin) meaning the women of the father's clan go inside.

${ }^{8}$ Les, you save? (Tok Pisin) meaning 'lazy, you know?'
} 
The women go round the pal na pidik giving first buai ${ }^{9}$, then tabu. Just as ToDoppel did last week, Charles shouts out "long namel" to encourage them to make sure very one gets it. I ask Charles why this kind of custom continues to be important. This is interesting. The immediate response is "bilong wanem em i kastom bilong mipela $^{10}$. Things have changed, but we still have to follow our tumbunas ${ }^{11}$ as you follow yours... It is about showing respect. Sure some people don't follow custom now, but it is important for teaching people a good life, and respect. There are some people now who think "i no gat narapela moa, mi tasol ${ }^{12 " .}$ Custom teaches otherwise... Even more interesting-Charles talks about how the kids need custom to stop them stealing and fighting. The minute he says this, a huge fight breaks out in the pal na pidik. One kid batters another to the ground, picks up one of the stakes and tries to kill him with it and has to be pulled off... Then Charles'father stands up and orders the young men to sit down. Then ToDawai comes forth a starts shouting angrily to the young people that they've got no respect. It was his son fighting ToGuria's son. ToGuria shouts after him as he's led away. ToGuria comes up to us. He is off his head. I think I smell rum, but Charles assures me it's powerful buai of the kind you take to see visions to design dances or pal na pidiks. Talks a bit about it. They use these kinds of buai for magic or Iniet ${ }^{13}$.

Fieldnotes 28.09.2002.

\footnotetext{
${ }^{9}$ Buai (Kuanua and Tok Pisin) meaning betel-nut (see below).

${ }^{10}$ Bilong wanem em i kastom bilong mipela (Tok Pisin) meaning 'because it is our custom'.

${ }^{11}$ Tumbunas (Tok Pisin) meaning 'ancestors.'

12 I no gat narapela moa, mi tasol (Tok Pisin) meaning 'there's no-one else, just me'.

${ }^{13}$ Iniet was a secret male sorcery society that is now largely believed to have been concerned with malicious sorcery. Most informants at the time of my fieldwork stated that iniet practices had either died out or were practiced in secret by a handful of malignant actors
} 
This extract from my notes from my first fieldwork at Matupit certainly illustrates a presentation of the idea that the namata is part of reproducing a desirable form of social order that is fundamentally tied in with the reproduction of the reciprocal obligations and interdependencies that are made and made apparent through its performance. Indeed, it might be fair to say that those repeating patterns are the desired social order. Charles' description of why customary ritual such as namata continues to be important is full of nods in this direction. When I mention to him that many people feel that it is too hard to 'work' custom today, his angry response clearly suggests that this is because of their misunderstanding of or lack of respect for the power of reciprocal obligation that such ritual ideally visibly reinforces and reproduces. These are people who, 'don't understand that if you give it comes back to you.' He goes on to tell me that the namata is fundamentally about 'respect'; a concept that is nearly always implicated in the Kuanua vernacular term wariru with an idea of respecting reciprocal obligations ${ }^{14}$. This association becomes clearer as he continues his explanation. He contrasts the ethic embodied in ritual with an imagined opposite; in this case the kind of 'individualism' that many fear is becoming more entrenched in modern Tolai life. Some people today might think, 'there's nothing else, just me' (i nogat narapela moa, mi tasol), but customary ritual teaches otherwise. Charles certainly expresses a commonly held vision of what ritual such as

\footnotetext{
${ }^{14} \mathrm{My}$ conversation with Charles took place almost entirely in Tok Pisin with some Kuanua and English words included for clarity of communication at various points. Where I paraphrase Charles in English in these notes that I wrote up later that day, it is largely an English translation of statements made in Tok Pisin. Tok Pisin extracts are direct verbatim quotations that I was able to write down immediately after the event. I do not know if the key Kuanua term 'wariru' was used in this conversation. However, on the basis of numerous other conversations with Charles and others I have no doubt that he would have used this term if we had switched to Kuanua and it was used by all Tolai I discussed these issues with as the translation of the English word 'respect' or the Tok Pisin word 'rispek'. The English term 'respect' potentially covers a number of ways of conducting relationship that both have an apparent link to idioms of reciprocal obligation and others that do not. By contrast, while I do not claim that the Kuanua term 'wariru' always must carry that explicit connotation, in my experience it nearly always could be fairly clearly linked to such an expectation (see e.g. Martin 2013:108).
} 
namata should achieve. But it is a vision that is undercut by other equally commonly expressed narratives concerning the contemporary failure of ritual to re-make reciprocal obligations in this manner and by the event's dramatic conclusion as well.

Indeed, the memory of this event is still fresh fifteen years after it occurred, standing out from the endless round of sharing cigarettes and cups of tea or waiting for food or lifts to town that were the ordinary day-to-day experience of fieldwork. In this regard the events of Matthew's namata fulfil an important aspect of ritual as it is commonly described; namely an event that breaks everyday routine and impacts upon its participants and observers alike with emotional intensity. For example, in RadcliffeBrown's (1922:122) vision of the role of ritual in Society imposing its norms upon its constituent individuals, ritual's efficacy often emerges through this divergence, such as in the contrast drawn in ritual mourning between the Andaman Islander's, 'everyday life', in which he is, 'black from head to toe', and his ritual presentation in which, 'he turns himself as white as possible from head to foot, by covering his body all over with clay', in order to mark his separation from, 'the world of living men.'

This depiction of the power of ritual as being based in a break from the everyday that then reinforces the social patterns of everyday behaviour can be found in the Tolai ethnographic literature as well. It seems to be present in Charles' presentation of the power of 'custom', a term that in this context is clearly referring to customary rituals such as the namata. Customary ritual makes visible and teaches the importance of respecting reciprocal obligations and interdependencies and this is the basis of respect in general. In teaching people 'respect', 'custom' also shows them a good life and it will stop the young men from engaging in anti-social behaviour such as fighting or 
stealing. Other such examples can be found earlier in the ethnographic record, such as Epstein's (1992:88-9) description of his conversations with an elder by the name of Turpui in the early 1960s. Turpui is describing a ritual known as a vevedek in which tabu collected through fishing is publicly displayed at the end of the fish-trap season. Turpui tells Epstein of a recent vevedek organised at the neighbouring village of Talwat and how emulating their achievement should be Matupit's aim. Turpui concludes by informing Epstein, 'Then our young men will see and begin to understand the ways of our forefathers.' Turpui's description of the power of ritual is clearly one in which the power of reciprocal interdependence is central- it is the display of tabu the social technology of marking such relations that is the heart of the ritual's power. Turpui's conversation with Epstein emerges out of an encounter with Turpui's son ToKaul, who is working on the beach making fish traps, in the expectation that this will bring the tabu that will enable young men such as him to pay bride wealth. When Epstein points out that a young man does not directly pay his own bride wealth, Turpui intervenes to explain that it is through this kind of labour that the young man proves himself ready for marriage and worthy of the support of older male relatives who will help to sponsor the payment. Hence the acquisition of tabu ties the young men into ongoing reciprocal interdependencies- with the bride's clan and also with older men who they are related to who help to sponsor the payment.

Turpui's depiction of the vevedek depicts a ritual whose power derives from the reciprocal interdependencies of everyday life, whilst simultaneously abstracting that power from its everyday contexts and specific relationships in order to present an appearance of power (the mass of tabu representing the labours of the entire village 
community) that will force the young men to understand the ways of their forefathers. In this regard, he presents an image of the power of ritual as being based upon the appearance of the abstracted power of everyday interdependencies that then by virtue of this powerful presentation feed back into those interdependencies and reinforce them, in a manner that is echoed forty years on by Charles in his conversation with me. Epstein observes that even in the 1960s that this vision was increasingly undercut by the tendency of young men to pay less attention to these rituals, to the extent that he felt that even Turpui knew that he was, 'talking into the wind' (op cit:89). And as we shall see, it is not only claims that customary ritual works by virtue of intensifying the power of everyday reciprocal interdependence that have continued through the decades, but also expressions of anxiety about its enduring power or doubts concerning its efficacy as an organizing principle of social relations that have become increasingly prominent and commonplace.

\section{Broken patterns}

Indeed, if there was a peculiar intensity of the impact of this event upon those of us present on that day was it was precisely that of its dramatic breakdown. I still remember clearly how the event exploded into violence at precisely the second that Charles had solemnly told me that such custom was needed to stop young men from fighting. Charles may describe the namata as a means by which customary respect is taught to the young and thereby reproduced across the generations. But other interpretations are available, such as the suspicion that ritual such as the namata is not only incapable of stopping the breakdown of respect, but is even one of the sites at which nascent social pressures leading to that breakdown are realised, by virtue of the 
ways in which they bring together large numbers of disenfranchised young men with no future in conditions of high excitement often exacerbated by consumption of alcohol and other substances. Hence the comment made to me after the event by ToDoppel, the elder who I describe as looking like Braveheart, 'This young men's manner, all this fucking fucking... I'm not happy with them'. ToDoppel's comments are of a piece with many similar comments that I heard during my fieldwork that expressed a concern with the effectiveness of ritual and whether it any longer embodied the power of reciprocal interdependencies upon which its power rested in the depiction of men like Turpui or Charles. Just as claims that customary ritual taught the young generalised respect through respect for reciprocal interdependencies have a long history at Matupit, so to do expressions of doubt as to the effectiveness or desirability of such claims. But although such expressions of doubt may have a long provenance, the nature of the concerns that are expressed seems to have changed, in a manner suggesting that rituals such as the namata provide a site where not only the reproduction of social order but also troubling social changes are made apparent and brought into being.

\section{Kaputin Junior's namata.}

"Last Saturday I attended a namata at Matupit for a son of Kaputin. During the nidok while the distribution was going on there was one young man who was already quite drunk who was lurching around with a half emptied bottle of whisky sticking out of his hip pocket. He came over to the pal na mamarikai ${ }^{15}$ and shouted obscenities at

\footnotetext{
${ }^{15} \mathrm{Pal}$ na mamarikai (Kuanua) literally translated as 'House of revelation'. This is the term that was used in the 1960s for what was referred to as Pal na pidik (see footnote 2 above) during my fieldwork in the early 2000s (see Epstein 1969:218-220).
} 
what was going on, saying it was all a lie. Then he went round and distributed buai as though to express his contempt for what was going on. Nobody present made any move to silence him or in any way interfere. After the nidok ${ }^{16}$ Kaputin made a speech in which he made it clear that he still grieved over his first son saying that he had prepared to do this for John but he had vakaina ra nuknukigu ${ }^{17}$. Now he was doing this for his other son, not because he was a malamalatene ${ }^{18}$, but so that others would see it and do likewise for their children. Incidentally, in the party was ToNgala ${ }^{19}$, a young man employed by Shell, whose namata I had attended earlier. He was said to have had a leading part in the building of the 'house'.

A few days later ToKonia called in at the house, and I asked about the young man in question. He was ToGuria ${ }^{20}$, a son of Pepelegi. It seems that he had served in the P.I.R ${ }^{21}$. and now he stayed at home. He probably lived by niil fishing. Apparently this kind of behaviour was nothing unusual, and he had clashed before with the elders. ToKonia himself went on to say that he thought that when men like Kaputin were dead there would be nobody to carry on, and such customs would finish. He himself felt that they should be allowed to fade out gradually, rather than that they should seek deliberately to abolish them. We then started talking about inter-racial marriage when a small group of Rapitok arrived. In the past few years a number of Matupi girls have married Europeans whilst there has also been ethnic

\footnotetext{
${ }^{16}$ Nidok conventionally refers the final stage of initiation in the secret male tubuan society. It is unclear to me precisely what this reference to 'nidok' means in this context.

17 Vakaina ra nuknukigu (Kuanua) literally translated as 'ruined my knowledge' (see below).

${ }^{18}$ A malamalatene (Kuanua) meaning a man who is big-headed or conceited (see Epstein 1998:24).

${ }^{19}$ Epstein's notes use this individual's real name. Here I change the name to a pseudonym that I have adopted to refer to this person elsewhere.

${ }^{20}$ Epstein's notes use this individual's real name. Here I change the name to a pseudonym that I have adopted to refer to this person elsewhere.

${ }^{21}$ The Pacific Islands Regiment.
} 
intermarriage. The eldest daughter of Kaputin has married a Papuan employed in the Administration. No view was expressed indicating disapproval. ToKonia thought that the 'race' would disappear, for already they could see through intermarriage the skin changed, a pala paka. Perhaps even the name Tolai would disappear in time. I omitted to mention that this discussion arose because when we had been discussing the disappearance of the namata ToKonia mentioned that fairly recently a group of young people had written letters to Radio Rabaul which had been discussed over the air suggesting that the moiety system should be abolished."

A.L. Epstein Fieldnotes 'Attitudes- changing social'. 29.12.1967

This extract from Epstein's unpublished Matupit fieldnotes evokes many of the same issues as the incident that I observed some 35 years later in the same village. A young man under the influence disturbs proceedings, leading to disquiet among those present. It suggests that ritual such as the namata has been the site for the discussion and shaping of changing patterns of social behaviour for generations; as evidenced not only by the extract itself, but even by the title that Epstein gave it in his fieldnotes. Epstein's own work is unusual for Melanesian ethnography of the period (indeed of any period) for the extent to which it eschews a vision of a fundamentally unchanging self-reproducing village-life for a focus on processes of social change occurring in the context of entanglements with colonial and global economic forces. The title of his main Tolai monograph, Matupit; Land, Politics and Change among the Tolai of New Britiain, published two years after the incident described in this extract, illustrates the focus of his attention. The descriptions of land disputes or conflicts over wage labour 
or political autonomy within his monograph tend to illustrate how existing patterns of village-based relational (particularly kinship) obligation are the means by which such battles are fought. In the process they end up being presented as both transformed and transformative as networks of (other) social relations. The description of ritual such as namata tends to have a slightly different framing in his published work however. This is largely described in the kind of ideal presentation seen in the earlier extract from his monograph in which it is presented as part of the reproduction of, 'an ongoing series of exchanges and distributions of various kinds'. These rituals are not seen as being immune from the processes of social change that Epstein is keen to describe, but rather than being analysed as changing processes within the context of connected changing networks, whose changes they mutually influence - they are either described as being stable processes operating with the context of other stable networks, or as being threatened with destruction by wider processes of change, in a manner that thereby contrasts with the more fluid descriptions of local land disputes or relations with colonial authorities that make up the bulk of the book ${ }^{22}$. Whereas Matupit contains lengthy and detailed depictions of particular land disputes, for example, designed to illustrate how they embody complex processes of social change, detailed depictions of particular ritual events tend to remain limited to unpublished fieldnote extracts such as the one quoted above.

The clue to the partial exclusion of this type of detailed ethnographic description, of the kind that Epstein as a leading member of the Manchester School, was in other

\footnotetext{
${ }^{22}$ This tendency is modified in his later work, following return visits to Matupit in the 1980s, in which he describes the revival of ritual practices but in a manner that begins to suggest the emergence of tensions over their meaning and efficacy caused by their changing position in wider socio-economic networks (e.g. Epstein 1999).
} 
contexts so keen to develop, perhaps appears within the extract itself. 'Traditional' Tolai land tenure based upon kinship and exchange obligations did not appear to be under threat to Epstein. Although it was implicated in wider complex processes of social change, it was not about to be simply removed or replaced with a different system. Rituals such as namata on the other hand appeared to be simply threatened with extinction by the Matupis incorporation into wider economic networks of wagelabour and cash-cropping, and this is how it was often described at the time by Tolai themselves, illustrated in the above extract, where Epstein's main research assistant, ToKonia, informs him that after Kaputin's death there will be no men left to keep such rituals going. Rituals such as the namata have survived, but ToKonia's prediction would be met with some agreement by many Matupi at the time of my fieldwork. The implication that was often voiced during my time at Matupit was that such rituals no longer embodied the power of reciprocal obligation that made them valuable and that despite their revival, after a period in the 1960s and 1970s when many thought that they would die out, that they were no longer constituted by or constitutive of, the kind or reciprocal obligation that had been their entire raison d'etre and source of their efficacy.

That fears of the failure of ritual to reproduce the socially cohesive power of reciprocal obligation have a long provenance, are also revealed at other points of Epstein's account. Here we see not only ToKonia's expression of the opinion commonly held at the time that such rituals were living on borrowed time, but also expressions of the desire to hasten their demise and that of the power of reciprocity that was at their heart. This is most clearly illustrated in the discussion of the letter suggesting the abolition of the 'moiety system' written by some young people to 
Radio Rabaul. Tolai are divided into two moieties, with marriage inside the moieties, being strictly forbidden in pre-colonial times. As late as the 1960s, Epstein (1969:203-4) observed that, ' $\ldots$ even though the penalty of death can no longer be exacted, [the taboo on intermarriage] is observed with the same stringency as in former times.' The moiety system, as described by Epstein, was fundamentally a system designed to promote ongoing 'exchange' marriage, between the two social groups who did not have any other existence or social purpose than the division of society into two groups linked to each other by ongoing exchange. As such intermoiety marriage marked the power of enduring and self-reproducing reciprocal obligation at the widest and most abstract social level. Rituals such as the namata are presented as a part of this cycle; the tabu collected is the outcome of previous cycles of reciprocal obligation and it is intended to go into furthering such cycles at a subsequent bride wealth payment that itself will then contribute to the wider abstract power of reciprocity instantiated through the 'moiety system.' That these things are seen as aspects of a greater whole is illustrated in the way that ToKonia introduces a discussion of the young people's letter in the context of a conversation about the namata. For the young people who wrote the letter, their attack on the moiety system should be seen as part of an attack on the stifling power of traditional customary obligation that Epstein notes was a common trope amongst young progressives at the time.

\begin{abstract}
Although this marks the most obvious deliberate attack on the customary power of reciprocity in this extract from Epstein's fieldnotes, there is another example as well. The young man, ToGuria who I was to encounter at the heart of another ritual disturbance 35 years later, enters the ritual space and loudly proclaims that the ritual
\end{abstract}


is, 'a lie' acts in a manner designed to draw attention to and subvert this power. The distribution of buai (betelnut) alongside tabu is a key part of the namata and other such rituals whose key foundation is the reconstitution of reciprocal obligations through the circulation of $t a b u$, and is itself a part of the recognition and reconstitution of these ongoing relations. By entering into the ritual space and seemingly randomly distributing buai in a manner designed to, 'express his contempt' for the proceedings, he expresses his contempt for that kind of distribution and the social power that it is intended to instantiate. But although his actions bear some similarity to the drunken fight that broke out at the namata that I attended 35 years later, there appears to be an important difference as well. His actions are a deliberate assault upon the customary power of reciprocity. Drunk as he is, he has a clear target and he attacks it in a politically loaded and considered manner. The young men who erupt in violence at the later namata appear to have no such conscious intent. It later emerged that their drunken rage had been fuelled by a disputed illegal drug deal in town a few days earlier. The namata might have survived ToGuria's attack on the ritual reciprocity underpinning it in 1967 . But the extent to which it really did demonstrate the socially cohesive power and efficacy of reciprocity that he sought to undermine and that Charles sought to defend is increasingly called into question.

Likewise, the 'moiety system' was never 'abolished' as the progressive young Tolai of 1967 desired. And given that it was not backed by a state or central authority it has hard to imagine who would have the power to 'abolish' it in conventional terms. But the situation by the early 2000s was very different from that described by Epstein for the late 1960 s. Intra-moiety marriage had gone from being unthinkable, to being broadly (if in some cases reluctantly) tolerated, and even some who were considered 
to be customary experts or leaders were now known to have married within their own moieties. Likewise, marriage or cohabitation without the exchange of tabu at bride wealth ceremonies had gone from being largely unthinkable (e.g. Epstein 1999:80) to being commonplace. Political attacks on the desirability of rituals based on reciprocal respect had largely been replaced by anxieties concerning the durability or effectiveness of ritual's role in the reproduction of such networks of reciprocal obligation.

\section{Reciprocity in question.}

The kinds of tendencies that would lead to increasing anxieties concerning the power or even the existence of reciprocity at the heart of ritual such as the namata can also be seen in embryo in Epstein's depiction. Epstein describes Kaputin's grief for his first son John. He describes John as having 'vakaina ra nuknukigu', to be literally translated as having 'ruined my knowledge'. Kaputin was the pre-eminent Big Man at Matupit during the time of Epstein's fieldwork, and was still talked of in tones of almost universal respect, 15 years after his death, at the time of my research in the early 2000s. His son, Sir John Kaputin was also talked about consistently at Matupit, having been the Member of Parliament for Rabaul from 1972 onwards and being one of the pre-eminent statesmen in the nation-state of Papua New Guinea, following its independence from 1975. Sir John was pre-eminent among the generation of young men who, as it was described to me, would have been groomed to become the new generation of Big Men in the 1960s and 1970s, but who left the village to go to university or pursue careers in politics and business that would have been closed to their fathers but were opening up to them as the Papua and New Guinea moved 
towards independence. It is this that Kaputin is likely referring to in his comment that he mourned for John, who had 'ruined' his customary knowledge by no longer being in the village to receive and reproduce it.

Sir John may have ruined his father's knowledge, but he acquired knowledge of a different type, using his education to carve out a career first as an anti-colonial leader and then as a leading figure in the post-colonial political establishment. Both Sir John's supporters and his opponents at Matupit agreed that he never became schooled in the ways of village life, having left it behind in order to immerse himself in the new forms of expertise that enabled him and others of his generation to lead the nation to independence. I was told that later in life, Sir John returned to the village to take his part in customary ritual, but that he was not able to fully engage. He was not able to eat much of the village foods that were often part of the circulation of reciprocal obligations at ritual events, having become used to 'white man's food', for example. Such shortcomings were justified as inevitable by his supporters but denigrated by his opponents as indicative of the increasing separation of 'Big Shots' such as Sir John from day-to-day village reciprocity.

Sir John may have returned to Matupit periodically and taken part in the ritual events, but despite this, for some Tolai at least, he never acquired the true knowledge that his father wished to transfer to him. The young man denouncing the namata as a 'lie' is probably best understood in the wider context of others who wished to break away from the power of customary reciprocity, that was common at the time, such as the young Tolai who wrote the letter attacking the moiety system to Radio Rabaul. The 
grassroots Tolai who denounced Sir John and other 'Big Shots' behind their backs for turning custom into a 'pastiche' 35 years later are probably best understood as expressing a different criticism; that whether the customary power of reciprocity was to be desired or not, that it was no longer made manifest by men such as Sir John in the same way that it was by their fathers. Kaputin may have been keen to perform such rituals primarily to encourage others to pass on the practices that they embodied to their own children as he had been unable to do for his own. As it turned out, his son later did engage in those ritual practices that Kaputin had been unable to pass on to him. But the extent to which either he, as one of the elite of the post-independence nation-state, or the young men whose drunkenness erupted into violence at the event that I witnessed, as representatives of those at the other end of the new economic hierarchy, were able to enact the ethics of reciprocal customary respect that the rituals were supposed to reproduce was clearly up for question.

Another figure is mentioned in this vignette who would also go on to be significant in the social changes enacted through ritual in the following decades. Epstein mentions the presence of a young man called ToNgala. His introduction to the narrative is, 'incidental' according to Epstein, suggesting perhaps that he is felt to be significant in some way beyond the fact that Epstein had previously attended his namata, but that Epstein is not able or willing to fully articulate or commit to. His significance is signaled in the other detail that Epstein gives us regarding his position; his employment by Shell. ToNgala was an immensely ambitious young man who, like Sir John, used his education to build up skills and expertise outside of the village. He worked for the Shell Oil Company for a number of years until he finally acquired the skills and the capital to begin running his own highly profitable petrol station in 
Rabaul Town in the 1980s and early 1990s, before its operations were halted by the Rabaul volcanic eruption of 1994. Unlike Sir John, whose life has been based in cosmopolitan centres such as Port Moresby, Cairns and Brussels however, ToNgala remained close to the village, not moving further away than Rabaul Town. Matupit village lay less than an hour's walk from the edge of Rabaul Town and was often considered as a peri-urban suburb of the town, as early as Epstein's first fieldwork in the 1950s (Epstein 1969). And unlike Sir John whose involvement with customary ritual was thus of a fly-in fly-out nature (often combined with his sporadic returns to the region for the purposes of political campaigning), ToNgala took a keen interest in customary ritual, acquiring a pre-eminent and leading position in customary ritual at Matupit by the time of my fieldwork. Yet despite these differences, Sir John and ToNgala were closely interlinked. They were political allies and ToNgala acted as Sir John's campaign and political agent in Rabaul for many years. And ToNgala's closeness to the village did not insulate from him the kind of criticism leveled at Sir John. Indeed, if anything it intensified it, as ToNgala ended up becoming blamed by many who were reluctant to openly criticize Sir John as being the bad influence on him who misled him about life 'back home' and used his connection to him for his own advantage.

\section{In search of respect.}

It is this history that sheds some more light on Charles' comments to me in 2002. When I mention to him that many people have told me that it is getting too hard to work custom today, his angry response is that they are 'lazy' and that they don't understand the power of reciprocity (or that, 'if you give it comes back to you'). 
Charles seems to frame the complaint that it is getting 'too hard' to work custom today as one based on a reluctance to expend the energy and effort or to devote time to the work that it entails. Yet I am certain that he would have been aware that such complaints more commonly had another basis; that the increased need for access to money made it ever harder to participate fully in customary events. Organising an event such as a namata today requires money and can place a real strain on those grassroots villagers at the bottom of an increasingly economically stratified postindependence PNG. In earlier ethnographic accounts from the 1960s, Tolai customary ritual is described as having been largely insulated from the money economy. It was impossible to buy large amounts of tabu with state currency and men such as Sir John and ToNgala's fathers could both be considered customary Big Men in the 1960s without having access to large amounts of money. In Epstein's account, the threat to custom was that young men with access to money would focus more on earning and spending money rather than acquiring tabu. Money was conceived of as a threat to the circuits of reciprocity embodied in the circulation of tabu at ritual by virtue of its separation from those circuits that thereby provided the young with an alternative focus of time and energy. By the start of the $21^{\text {st }}$ century the situation appeared somewhat different to most Matupit residents. Tabu was bought in bulk by so-called Big Shots such as Sir John and ToNgala, many of whom would fly to neighbouring Pacific Islands nations, such as Vanuatu or the Solomon Islands to buy the shells that made it. To Ngala had acquired a pre-eminent position in customary ritual and had apparently acquired much secret customary knowledge through the use of his tabu. But whereas in previous generations the acquisition of such tabu was said to itself mark the extent of a man's engagement with the give-andtake of daily village life (as is exemplified in Epstein's account of his conversations 
with Turpui for example), the tabu that was bought by this new generation of leaders was seen by many grassroots villagers as marking a different kind of social power; one that was removed from the cycles of reciprocal obligation and relation that ideally made it powerful.

Even though ToNgala had remained close to the village and had immersed himself in customary ritual in a manner that Sir John had not, his involvement was still denigrated (largely behind his back) as the tabu that secured his pre-eminent position was (rightly or wrongly) claimed to have its source in these national and international business and political connections (not in the kinds of village-level reciprocal bonds that had secured his father's customary power). We see early signs of the potentially transformative power of these connections as they enter the ritual space in Epstein's description, but they are not yet fully visible to anyone, as the participation of a young man, 'employed by Shell' is mentioned incidentally and in passing. The story of the drunk young man consciously attacking the ethic of reciprocal obligation with his parody of buai distribution is the centerpiece of Epstein's description, but ironically enough it was the incidental figure of ToNgala, who sincerely believed himself to be the genuine custodian of authentic customary ritual, who went on, in the eyes of many of his opponents, to be the executioner of the genuine reciprocal ethic that made ritual matter.

Charles was a 'child' of ToNgala's clan ${ }^{23}$ (his father also mentioned in this extract was a member of ToNgala's clan) and as such closely linked to ToNgala and Sir John. In 2002, the tide turned against Sir John and he was defeated in a landslide in a

\footnotetext{
${ }^{23}$ See Martin (2013:34).
} 
general election. The main impetus behind this shock was the perception that he had become too distant from the village and increasingly treated grassroots villagers with disdain. On one occasion at an election rally, he accused villagers who asked for the return of government services, such as a school, to Matupit, of wanting to be 'spoonfed'; a dismissal that sealed his fate with many of his previous grassroots supporters. Due to their close relatedness to ToNgala, Charles and others (though not all) in his immediate kinship network tended to be amongst the minority of grassroots villagers who remained most loyal to both Sir John and ToNgala. As such he is more likely than most to dismiss the claim of other grassroots villagers that they are excluded from full participation in ritual because of lack of money and to present that as a moral failing caused by the lack of desire to work hard enough at reproducing reciprocal relational obligations through ritual. He is also more likely than most to dismiss these villagers' claims that the likes of ToNgala have themselves destroyed the power of reciprocity at the heart of ritual by introducing money-purchased tabu and increasingly insulating themselves and their businesses from demands based on reciprocal obligation in non-ritual contexts. Both sides of this debate see the reproduction of relations of reciprocal obligation through customary ritual as being under threat. For Charles they are threatened by the laziness and moral turpitude of those who do not see how important the reproduction of these obligations is. For other grassroots critics they have already been weakened by the actions of the new elite.

In recent years, some accounts of similar ritual and exchange processes have attempted to criticize the supposed assumption of reciprocity that underpins classical anthropological analyses (e.g. Rasmussen 2015). But rather than attempting to 
classify particular moments of transfer as being either reciprocal or not, what this material suggests is that we should look at reciprocity as a performative perspective on chains of social relations that comes in and out of being depending on the standpoint one takes. For many grassroots villagers the Big Shots' tabu does not embody reciprocal obligation because they foreground the chains of economic and political entanglement that the Big Shots' ability to distribute tabu emerges from (chains of relations that in ToNgala's case began all the way back with his employment at Shell in the mid-1960s). For others who choose not to foreground these networks by contrast, it is the Big Shots who help to keep customary reciprocal obligation instantiated through ritual alive, by providing the money and tabu that makes its survival possible. The Big Shots are seen in this framing as keeping the reproduction of reciprocal obligation going, but their sacrifice is threatened by a growing laziness among the grassroots who are characterized as wishing to be 'spoonfed'- a desire for one-way dependence that denies reciprocal obligation- or wishing to remove themselves from custom altogether to concentrate on the survival of themselves and their families in the modern cash economy. These conflicting perspectives that bring reciprocity in and out of vision depending on the networks of relations that they foreground and occlude are themselves performative, helping to shape the outcome of future webs of relational obligation and ritual effect.

\section{The power of ritual}

In Epstein's writings there is a clear sense that ritual such as the namata has a real social power and efficacy. Even the young man who consciously subverts the ritual acts in a manner that suggests that there is something in the ritual that he feels a need 
or desire to undermine. His courage in doing so might not only be down to the half bottle of whisky that he has consumed, but also a sense that the ground was already beginning to slip from beneath the Big Men's feet. But like the letter writers to Radio Rabaul, he still felt the need to make a deliberate attack on the reproduction of reciprocal obligations underpinning the ritual, suggesting that he still felt a power there that it was worthwhile to confront. By contrast, at the time of my fieldwork, although there was clearly a desire in some quarters to argue that customary ritual did have a social power, it was tempered with an anxiety about exactly what that power was (did it really reproduce the kinds of village-level reciprocal obligations that it was supposed to) and consequently about the extent to which it was efficacious in creating the kind of social order that reciprocal obligation that it was ideally described as producing ${ }^{24}$. Charles' statement that custom will teach the young men not to fight and steal by virtue of this power is of course immediately undercut by the fight that breaks out (allegedly sparked by the theft of money gained from an illegal drug deal) immediately upon its pronouncement. His statement was a variation of a kind that was often publicly made at such events, that was more expressive of a desire to use customary ritual in this manner than it was a universally accepted depiction of how it worked in practice. All sorts of figures, from the young men drunk on jungle juice and high on cannabis, to the Big Shots driving in to the village with dollar-bought tabu could be seen from different angles as threatening the reproduction of reciprocal obligation and the consequent recreation of social order that such ritual was supposed to create.

\footnotetext{
${ }^{24}$ The concept of 'obligation' itself changes in definition and tone in different conversational contexts, both academic and non-academic (Testart 1998, Guyer 2012). Testart's attempt to distinguish between, 'feelings of obligation and what is obligatory' (Testart 1998:99) usefully reminds of us the manner in which the nature and existence of 'obligation' is itself a matter of social-contextual perspective.
} 
But such statements are still vitally important as they express the hope amongst many that ritual could create a kind of social order based upon 'respect'. Customary ritual is here imagined as a force that might discipline the young into correct behaviour. This is not necessarily to be conceived of as an alien power standing over the Individual taking the form of a reified Society that impresses itself upon its members, in the manner that both Strathern (1988:8) and Gluckman (1963:18) in their different ways take Radcliffe-Brown to task for presuming. But the power of this ritual reciprocity does appear in this presentation to ideally take on the form of a selfreplicating structure of relations that produces persons obedient to its own reproduction, whether or not that structure is best described as existing as an independent entity outside of and in some way opposed to their own existence. According to Charles custom such as the namata 'teaches' people 'good life and respect'. The power of reciprocity made and made visible in such ritual is conceived of as ideally having the effect making both good persons and social solidarity (however conceived). Yet what ethnographic exploration of specific instances of namata reveals is that just as it can be conceived of as the site where the social order that makes good persons is reproduced and revealed, that it has long also been capable of being viewed as the very place where the potential fragility of that order is most brutally exposed.

Claims to the efficacy of ritual of the type made by Charles are best understood not as statements of fact or descriptions of the overt or underlying truth of the nature of ritual, but ultimately as performative attempts to use the space for the 'working through' of paradoxes of life that rituals provide in one particular direction. As 
Austin (1979:251) might suggest, our attention should not so much be towards what the utterance, 'means.... as to what was the force, as we may call it, of the utterance.' Such performative utterances do not always shape the social contexts of which they are a constituent element as successfully as their authors may intend; as the eruption of violence at the precise moment that Charles was solemnly describing the role of ritual in teaching the young respect illustrates. There may be times when socially sanctioned understandings of ritual as a socially reproductive practice seem largely unchallengeable and when the performative utterances that this is ritual's purpose seem to largely unproblematically be fulfilled in practice. But ritual is always capable of being interpreted as having outcomes whose performative force leads to the reproduction or emergence other kinds of relations. Statements such as Charles' are themselves attempts to temporarily fix the ambiguities that rituals evoke in a particular direction, but as the different instances of the namata ritual detailed here demonstrate, both these statements and the ritual events that they help to constitute can just as easily create spaces for the explosion of different responses that exceed the attempt to make ritual into a tool for the recreation of any particular desired social effect. 


\section{References}

Austin, J. 1979. Performative Utterances. In J. Urmson and G. Warnock (eds.) J.L Austin; Philosophical Papers. Pp. 233-252, Oxford. Clarendon.

Epstein, A.L. 1969. Matupit: Land, Politics and Change among the Tolai of New Britain. Berkeley. University of California Press.

Epstein, A.L. 1992. In the Midst of Life: Affect and Ideation in the World of the Tolai. Berkeley. University of California Press.

Epstein, A.L. 1998. Tubuan: The Survival of a Male Cult among the Tolai. Journal of Ritual Studies 12(2):15-28.

Epstein, A.L. 1999. Gunantuna: Aspects of the Person, the Self and the Individual among the Tolai. Bathurst. Crawford Publishing House.

Gluckman, M. 1963. Order and Rebellion in Tribal Africa. London. Cohen and West. Martin, K. 2013. The Death of the Big Men and the Rise of the Big Shots: Custom and Conflict in East New Britain. New York. Berghahn Books.

Guyer, J. 2012. Obligation, Binding, Debt and Responsibility: Provocations about Temporality from Two New Sources. Social Anthropology. 20(4):491-501.

Radcliffe-Brown, A. 1922. The Andaman Islanders: A Study in Social Anthropology.

Cambridge. Cambridge University Press.

Rasmussen, A. 2015. In the Absence of the Gift. New York. Berghahn.

Simet, J. 2014. Namata: Ritual Seclusion among the Tolai of New Britain.

Strathern, M. 1988. The Gender of the Gift: Problems with Women and Problems with Society in Melanesia. Berkeley. University of California Press.

Tateyama, H. 2006. Tubuan: History, Tradition and Identity among the Tolai of Papua New Guinea. PhD Thesis. University of British Columbia. 
Testart, A. 1998. Uncertainties of the Obligation to Reciprocate: A Critique of Mauss.

In W. James and N. Allen (eds.) Marcel Mauss: A Centenary Tribute. Pp. 97-110.

New York. Berghahn. 